\title{
Evaluation of Antibacterial and Antifungal Activity of Cow Urine against Some Seed Borne Microflora
}

\author{
Tanmay Ghosh ${ }^{1 *}$ and M.K. Biswas ${ }^{2}$ \\ ${ }^{1}$ Department of Microbiology, Rabindra Mahavidyalaya, Champadanga, \\ Hooghly, W.B., India \\ ${ }^{2}$ Department of Plant Protection, Palli Siksha Bhavana, Viswa-Bharati, \\ Sriniketan, Birbhum, W.B., India \\ *Corresponding author
}

\begin{abstract}
A B S T R A C T
Cow urine therapy and all traditional practices from Indian systems of medicine have a strong scientific base. The cow has proved to be a boon in the areas of agriculture, science

Keywords

Antibacterial,

Antifungal, Cow

Urine, Seed borne microflora

\section{Article Info}

Accepted:

16 April 2018

Available Online:

10 May 2018 and technology, industry, energy, medicine etc. for the development of any nation, in addition being eco-friendly in nature. In the present study the antibacterial and antifungal potentials of cow urine were investigated. Total 9 pathogenic and non-pathogenic bacterial and fungal cultures were used as test organism against three different cow urine samples. Fungal culture includes Aspergillus sp, Rhizopus sp, Mucor sp, Penicillium sp, Alternaria sp, Macrophomina sp and bacterial culture include Bacillus subtilis, Pseudomonas sp, Streptococcus sp. The highest zone of inhibition was shown against Aspergillus sp while the smallest zone of inhibition was shown against Macrophomina sp in fresh cow urine. The highest zone of inhibition was shown against Aspergillus sp while the smallest zone of inhibition was shown against Pseudomonas sp in photoactivated cow urine. The highest zone of inhibition was shown against Bacillus subtilis while the smallest zone of inhibition was shown against Pseudomonas sp in sterile cow urine. Based on cumulative effect against the test organism, the raw urine sample was found to be the most efficient inhibiting all the 9 test cultures but the activity was reported low against fungi compared bacteria.
\end{abstract}

\section{Introduction}

'The cow' is a mobile medical dispensary and cow urine is a panacea of all diseases (Pathak and Kumar, 2003). The cow urine, one of the ingredients of 'Panchagawya' is capable of treating many curable as well as incurable diseases and has been used extensively in ayurvedic preparations since time immemorial as cited in ancient holy texts like Charaka
Samhita, Sushruta Samhita, Vridhabhagabhatt, Atharva Veda, Bhavaprakash, Rajni Ghuntu, Amritasagar, etc (Pathak and Kumar, 2003). A lots of research has been conducted in Cow Urine Treatment and Research Centre, Indore over the past few years and it has been reported that gomutra is capable of curing blood pressure, blockage in arteries, arthritis, diabetes, heart attack, cancer, thyroid, asthma, psoriasis, eczema, prostrate, fits, AIDS, piles, 
migraine, ulcer, acidity, constipation, gynecological problems, ear and nose problems and several other diseases (Jain et al., 2010). The use of cow urine in India can be traced back to the Vedic and probably prevedic period also. Cow urine as such has been most widely referred, used and venerated animal urine owing to its immense therapeutic speciality. While externally it has been used as lotion, ointments and bath, but, internally it has been used in preparation of oral medications and drinks. There is existence of innumerable instances in various ancient medical texts of the curative properties of cow urine for a horde of human ailments. In ancient Indian system of medicine, urine of cow was accepted, used almost as a broad spectrum antibiotic quite akin to that of twenty first century. The cow urine not only used against ailments of diseases as therapeutic agents but also have several other uses as in agriculture and sericulture sectors. So this article attempts to bring forth the diversified use of this heretical potion as was in vogue in ancient Indian system of medicine as gleaned from the ancient medical texts and current scientific findings. In Veda, cow is considered the most valuable animal and is called Mother of all. Different products obtained from cow like urine, dung, milk, ghee and curd are used widely in number of Ayurvedic formulations (Shah, 1997) As per Ayurvedic literatures cow urine possess many medicinal properties and is used in curing number of diseases like skin diseases, kidney problems, epilepsy, anemia, constipation, respiratory disease etc (Krishnamurthi et al., 2004; Chauhan et al., 2001). Due to its therapeutic values majority of rural population in India use cow urine as a folklore remedy to get rid of various diseases. Nowadays, different preparations of cow urine like urine distillate, photo- activated urine, fresh urine, sterile urine have been marketed with cheap and affordable prices (Edwin et al., 2008). Thus the aim of the present work is to study antibacterial potential of photo- activated cow urine, fresh cow urine, cow's urine Fungi are one among the important aetiological agents of plant diseases. Fungi cause diseases in plants both in field and storage. The fungal infection of plants results in poor yield of crop and hence results in considerable economic loss. In severe cases, crop losses exceeding $>50 \%$ can occur due to fungal infections. The management of mycotic diseases of plants mainly focuses the use of chemical agents. The use of synthetic fungicides appears promising but suffers from several drawbacks such as high cost, environmental pollution, adverse effects on non-target organisms and the emergence of resistant strains of pathogenic fungi. Natural products including cow urine and cow urine based formulations have been investigated for antifungal activity and the results appeared promising (Swami and Alane, 2013; Ashlesha et al., 2013; Gotora et al., 2014; Ashlesha and Paul, 2014; Kekuda et al., 2016). Cow urine is shown to exhibit potent inhibitory activity against a wide range of pathogenic microbes including phytopathogenic fungi (Akhter et al., 2006; Deshmukh et al., 2012; Kambar et al., 2013; Randhawa and Sharma, 2015; Aruna and Spadmapriya, 2016; Ruchira et al., 2016). Similarly, formulations based on cow urine and plants have shown to possess inhibitory effect against various pathogenic microorganisms (Yadav et al., 2008; Tiwari and Das, 2011; Shanthi et al., 2011; Rakesh et al., 2013; Mehta and Khan, 2014; Kekuda et al., 2014). The present study was carried out to investigate antifungal and antibacterial potential of cow urine against 6 phytopathogenic fungi and 3 bacteria.

\section{Biochemical analysis of cow urine}

The laboratory analysis of cow urine shows that it contains nitrogen, sulphur, phosphate, sodium, manganese, iron, silicon, chlorine, magnesium and mineral as its mineral content; malic, citric, titric, succinic, carbolic acids; 
calcium salts, Vitamins A, B, C, D, E; lactose, enzymes, creatinine, hormones and gold acids - all needed in smaller amounts by the human body to balance the "tridosha"- vata, pitta and Kapha. Any deficiency or excess of these substances inside the body causes disorders. Cow urine contains all of these substances with having a balanced proximate composition. Therefore, consumption of cow urine restores the balance of these substances and thus helps in curing from incurable diseases. The various mineral and chemical constituents present in cow urine are attributed with different biochemical roles in the body (World Intellectual Property Organization, 2013). For example nitrogen removes blood abnormalities, toxins and is a natural stimulant of urinary system; sulphur support peristaltic movement in large intestine and purified blood; copper control unwanted fat; iron help in production of haemoglobin and erythropoiesis; phosphorus helps in removal of stones from urinary tract; sodium purifies blood and acts as an antacid; potassium cures rheumatism and increase appetite, muscular strength, stamina and activeness; manganese prevents growth of germs, tissue nacrosis; calcium is a blood purifier and strengthens bones; gold is a germicidal and increases immunity. Our body contains many micronutrients that give us strength for life, but these micro-nutrients are flushed out of our body when we urinate. Cow urine meets the deficiency of these micronutrients in the body. It maintains the balance of these substances in our body and cures even the so called incurable diseases (Kirtikar and Basu, 2003).

\section{Mechanisms of action of cow urine}

Different fractions of CU possess antimicrobial activity due to the presence of certain components like volatile and nonvolatile ones (Jarald et al., 2008; Mohanty et al., 2014; Hu et al., 2007; Shaw et al., 2007).
Presence of urea, creatinine, swarn kshar (aurum hydroxide), carbolic acid, phenols, calcium, and manganese has strongly explained the antimicrobial and germicidal properties of CU (Achliya et al., 2004; Jain et al., 2010; Kumar, 2001). Presence of amino acids and urinary peptides may enhance the bactericidal effect (Badadani et al., 2007) by increasing the bacterial cell surface hydrophobicity. CU enhances the phagocytic activity of macrophages. Higher amounts of phenols in fresh CU than CU distillate (CUD) makes it more effective against microbes. After photo-activation, few biogenic volatile inorganic and organic compounds such as $\mathrm{CO} 2, \mathrm{NH} 3, \mathrm{CH} 4$, methanol, propanol and acetone, and some metabolic secondary nitrogenous products are also formed (Upadhyay et al., 2010). Photo-activated CU (PhCU) becomes highly acidic in comparison to fresh CU. An increase in bactericidal action may be due to a significant decrease in $\mathrm{pH}$, presence of inorganic phosphorus, chloride and dimethylamine may also play an important role (Naotoshi et al., 2007), along with increased formation of some reactive compounds like formaldehyde, sulfinol, ketones and some amines during photoactivation and long term storage (Türi et al., 1997). CU prevents the development of antibacterial resistance by blocking the Rfactor, a part of plasmid genome of bacteria (Chauhan and Singhal, 2006). CU contains phenolic acids (gallic, caffeic, ferulic, ocoumaric, cinnamic, and salicylic acids) which have antifungal characteristics (Singh et al., 2012). Antioxidant property of uric acid and allantoin present in CU correlates with its anticancer effect. CU reduces apoptosis in lymphocytes and helps them to survive better. This action may be due to the free radical scavenging activity of the urine components, and these components may prevent the process of aging (Jarald et al., 2008). It efficiently repairs the damaged DNA. Daily consumption of $\mathrm{CU}$ improves immunity due to the presence 
of swarn kshar and fastens the wound healing process, which is due to allantoin. $\mathrm{CU}$ enhances the immunocompetence by facilitating the synthesis of interleukin-1 and 2 (Chauhan, 2004; Singla and Garg, 2013), augments B - and T- lymphocyte blastogenesis, and $\operatorname{IgA}$, IgM and $\operatorname{IgG}$ antibody titers (Kumar, 2013). Early morning first voided $\mathrm{CU}$ is more sterile and have more macro and micronutrients along with other enzyme/urea content could be more effective (Pescheck-Böhmer and Schreiber, 1999).

\section{Materials and Methods}

\section{Collection and preparation of cow urine}

Cow urine was collected from the wellmaintained Goshala of local area. The cow selected for this research was a healthy Nagori cow, aged seven years being fed a uniform diet and undergoing regular vaccination schedule. Fresh cow urine was collected in sterile screw cap bottles and brought to the laboratory for testing. It was filtered by ordinary filter paper before being subjected to further testing. Sterile cow urine was prepared by sterilizing the urine sample maintained in an autoclave at a temperature of $121^{\circ} \mathrm{C}$ and 15 $\mathrm{lb} / \mathrm{in} 2$ pressure for 15 minutes. Photo activated cow urine was prepared by keeping the urine in transparent sterile bottle for 72 hours in sunlight. Thus purified, fresh and photoactivated cow urine were stored at $4{ }^{\circ} \mathrm{C}$ for further future use as per experimental requirements. Different samples of cow urine thus obtained are:

Fresh cow urine,

Sterile cow urine,

Photo activated cow urine,

\section{Collection of microorganisms}

All bacterial and fungal strains were isolated from different oil and cereal crops seed. Seeds were incubated in Potato dextrose Agar (PDA) and Standard blotter paper for 5 to 7 days. Then the microbial colony on agar and paper plate were isolated and identified. Then they were made slant culture separately. Then they were stored in room temperature for further use.

\section{Medium}

PDA plates were used for the growth of fungal strain and MHA plates were used for the growth of Bacterial strain. $3.9 \mathrm{~g}$ of Potato dextrose agar and $3.8 \mathrm{~g}$ of Mueller Hinton Agar (MHA) was added to $100 \mathrm{ml}$ of distilled water in separate conical flask and autoclaved at $121^{\circ} \mathrm{c}$ for 15 minutes at $15 \mathrm{lbs}$ and poured in sterile petri plates up to a uniform thickness of approximately $4 \mathrm{~mm}$ and the agar is allowed to set at ambient temperature and used. A few slants were made for storage of Bacterial and fungal culture.

\section{Microbiological assay}

\section{Well diffusion method}

The antimicrobial activity of cow urine was tested by preparing 5 different percentage of cow urine. Percentages were made by dissolving cow urine in sterile water. Five percentages $20 \%, 40 \%, 50 \%, 70 \%, 100 \%$ were taken for the analysis of antibacterial activity. A hollow tube was heated and pressed above the inoculated agar plate. It was removed immediately by making a well in the plate; two and three wells on each plate were made.

\section{Inoculums and incubation}

$0.1 \mathrm{mg}$ of bacterial and fungal cultures was transferred to the agar plates. The inoculated plates were allowed to stand for $5 \mathrm{~min}$, before making wells for different percentages to be tested. The percentages of cow urine were 
loaded at different concentrations in the well on agar plate. Then bacterial and fungal cultures and incubated at normal room temperature for 24-48 hours in an incubator.

\section{Procedure of determining the efficacy of cow urine as antifungal agent}

The five percentages $(20 \%, 40 \%, 50 \%, 70 \%$ and $100 \% \mathrm{v} / \mathrm{v}$ ) of cow urine were prepared. $5 \mathrm{~mL}$ of different concentrations of cow urine was amended in $15 \mathrm{~mL}$ of potato dextrose agar medium and mixed thoroughly by stirring. Control was maintained in which distilled water was used instead of cow urine. The medium was autoclaved and poured into sterilized Petri plates and left. The fungal discs of $5 \mathrm{~mm}$ diameter were taken from actively growing cultures by using cork borer and the discs were transferred aseptically on PDA plates poisoned with cow urine. Plates were incubated at $28 \pm 2 \circ \mathrm{C}$ temperature in incubator for 7 days. After 7 days plates were observed and colony diameters were measured with the help of ruler. The percent of inhibition was calculated using the following formula given below:

Percent inhibition of mycelia growth (\%)

$\mathrm{I}=\mathrm{100(C-T)}$

Where $I$ is inhibition percentage, $C$ is colony diameter in control plates, and $T$ is colony diameter in poisoned plates.

\section{Statistical analysis}

After incubation the diameter of zone of inhibition around the well was measured using zone reader. Corresponding 3 values of zones of inhibition for each percentage of cow urine were taken. The values so obtained were compared within the group (same percentage of cow urine) and with different groups (different percentage of cow urine) for different bacteria and fungi and statistical analysis was done

\section{Results and Discussion}

The results of antibacterial and antifungal potential of different cow urine preparation are shown in Table 1. The result of the present study shows that antibacterial and antifungal activity of fresh cow urine is more active than photoactivated urine. These observations are likely to be the result of the presence of certain volatile and non-volatile components present in urine (Fig. 1-6).

The antibacterial activity of photoactivated urine may be due to its acidic $\mathrm{pH}$. It may also be due to presence of more cations and formation of nitrosoamines. It was observed that gram positive organisms were more sensitive than gram negative organisms. These observations are likely to be the result of the differences in cell wall structure between gram positive and gram negative bacteria, with gram negative outer membrane acting as a barrier to many environmental substances. In the present studies six fungal species namely Aspergillus sp, Rhizopus sp, Mucor sp, Penicillium sp, Alternaria sp, Macrophomina sp and three bacterial cultures include Bacillus subtilis, Pseudomonas sp, Streptococcus sp are used. All percentages $(20,40,50,70,100)$ of cow urine were effective against the growth of the fungus which exhibited the significant inhibition in the growth of fungal plant pathogens. With increase in concentration of cow urine there was corresponding increase in the inhibition of vegetative growth of the fungal pathogens.

The diameter of the fungal colonies in poisoned plates was lesser when compared to control plates and it indicates the antifungal effect of cow urine. 
Table.1 The microbial zones of inhibition values

\begin{tabular}{|c|c|c|c|c|c|c|c|c|c|c|}
\hline \multirow{3}{*}{$\begin{array}{l}\text { Types } \\
\text { of cow } \\
\text { urine }\end{array}$} & \multirow{3}{*}{$\begin{array}{l}\text { Percent } \\
\text { age of } \\
\text { cow } \\
\text { urine }\end{array}$} & \multicolumn{9}{|c|}{ Diameter of zone of inhibition (mm) } \\
\hline & & \multicolumn{9}{|c|}{ Name of the seed microflora (bacterial and fungal species) } \\
\hline & & $\begin{array}{l}\text { Aspergillus } \\
\text { sp }\end{array}$ & $\begin{array}{l}\text { Rhizopus } \\
\text { sp }\end{array}$ & Mucor sp & $\begin{array}{l}\text { Penicillium } \\
\text { sp }\end{array}$ & $\begin{array}{l}\text { Alternaria } \\
\text { sp }\end{array}$ & $\begin{array}{l}\text { Macro } \\
\text { phomina sp }\end{array}$ & $\begin{array}{l}\text { Bacillus } \\
\text { subtilis }\end{array}$ & Pseudomonas sp & $\begin{array}{l}\text { Streptococcus } \\
\text { sp. }\end{array}$ \\
\hline \multirow{5}{*}{ Fresh } & $20 \%$ & $15.26 \pm 1.0$ & $12.22 \pm 3.0$ & $12.12 \pm 1.0$ & $13.04 \pm 0.0$ & $13.63 \pm 2.0$ & $11.42 \pm 1.0$ & $14.08 \pm 1.0$ & $12.38 \pm 3.0$ & $13.08 \pm 3.0$ \\
\hline & $40 \%$ & $17.23 \pm 3.0$ & $14.00 \pm 0.0$ & $13.25 \pm 3.0$ & $15.48 \pm 1.0$ & $14.13 \pm 1.0$ & $13.23 \pm 3.0$ & $16.45 \pm 1.0$ & $13.22 \pm 1.0$ & $16.07 \pm 1.0$ \\
\hline & $50 \%$ & $18.63 \pm 0.0$ & $15.21 \pm 1.0$ & $14.89 \pm 1.0$ & $16.78 \pm 3.0$ & $15.24 \pm 3.0$ & $14.22 \pm 1.0$ & $17.55 \pm 3.0$ & $15.02 \pm 1.0$ & $17.10 \pm 1.0$ \\
\hline & $70 \%$ & $21.03 \pm 1.0$ & $18.05 \pm 0.0$ & $17.05 \pm 3.0$ & $19.12 \pm 1.0$ & $18.16 \pm 1.0$ & $16.56 \pm 0.0$ & $20.62 \pm 1.0$ & $17.88 \pm 3.0$ & $20.11 \pm 3.0$ \\
\hline & $100 \%$ & $24.42 \pm 3.0$ & $21.02 \pm 3.0$ & $20.22 \pm 0.0$ & $21.06 \pm 2.0$ & $21.72 \pm 1.0$ & $19.66 \pm 1.0$ & $23.28 \pm 1.0$ & $19.72 \pm 2.0$ & $22.21 \pm 1.0$ \\
\hline \multirow{5}{*}{$\begin{array}{l}\text { Photo } \\
\text { activated }\end{array}$} & $20 \%$ & $13.25 \pm 1.0$ & $11.28 \pm 1.0$ & $11.57 \pm 1.0$ & $12.37 \pm 1.0$ & $12.57 \pm 3.0$ & $11.44 \pm 1.0$ & $13.64 \pm 3.0$ & $11.14 \pm 2.0$ & $11.54 \pm 0.0$ \\
\hline & $40 \%$ & $15.35 \pm 3.0$ & $13.80 \pm 0.0$ & $12.35 \pm 0.0$ & $14.19 \pm 0.0$ & $13.87 \pm 0.0$ & $12.00 \pm 3.0$ & $15.31 \pm 0.0$ & $12.01 \pm 1.0$ & $15.34 \pm 2.0$ \\
\hline & $50 \%$ & $16.58 \pm 0.0$ & $14.87 \pm 1.0$ & $13.18 \pm 1.0$ & $15.25 \pm 3.0$ & $14.34 \pm 1.0$ & $13.69 \pm 2.0$ & $16.59 \pm 2.0$ & $14.79 \pm 3.0$ & $16.13 \pm 1.0$ \\
\hline & $70 \%$ & $19.79 \pm 1.0$ & $17.69 \pm 3.0$ & $16.94 \pm 3.0$ & $18.31 \pm 2.0$ & $17.31 \pm 2.0$ & $15.70 \pm 0.0$ & $19.29 \pm 1.0$ & $16.47 \pm 2.0$ & $19.51 \pm 3.0$ \\
\hline & $100 \%$ & $22.93 \pm 3.0$ & $20.35 \pm 1.0$ & $19.58 \pm 0.0$ & $20.21 \pm 1.0$ & $20.94 \pm 3.0$ & $18.49 \pm 1.0$ & $22.19 \pm 3.0$ & $18.40 \pm 02$ & $20.42 \pm 1.0$ \\
\hline \multirow{5}{*}{ Sterile } & $20 \%$ & $11.48 \pm 1.0$ & $10.29 \pm 2.0$ & $10.28 \pm 1.0$ & $11.87 \pm 0.0$ & $11.22 \pm 2.0$ & $10.57 \pm 3.0$ & $12.28 \pm 1.0$ & $10.16 \pm 3.0$ & $11.11 \pm 0.0$ \\
\hline & $40 \%$ & $13.25 \pm 0.0$ & $12.94 \pm 1.0$ & $11.25 \pm 1.0$ & $12.83 \pm 3.0$ & $12.16 \pm 1.0$ & $11.47 \pm 0.0$ & $14.42 \pm 2.0$ & $11.31 \pm 1.0$ & $14.64 \pm 2.0$ \\
\hline & $50 \%$ & $14.72 \pm 2.0$ & $13.05 \pm 1.0$ & $12.78 \pm 3.0$ & $15.90 \pm 0.0$ & $13.05 \pm 3.0$ & $13.43 \pm 1.0$ & $15.34 \pm 3.0$ & $13.66 \pm 0.0$ & $17.31 \pm 3.0$ \\
\hline & $70 \%$ & $17.00 \pm 1.0$ & $16.35 \pm 0.0$ & $15.34 \pm 1.0$ & $17.05 \pm 3.0$ & $16.52 \pm 1.0$ & $15.61 \pm 3.0$ & $18.49 \pm 1.0$ & $15.31 \pm 1.0$ & $18.97 \pm 1.0$ \\
\hline & $100 \%$ & $20.94 \pm 3.0$ & $19.85 \pm 3.0$ & $18.80 \pm 0.0$ & $18.58 \pm 1.0$ & $19.31 \pm 3.0$ & $18.54 \pm 1.0$ & $21.38 \pm 3.0$ & $17.84 \pm 3.0$ & $20.28 \pm 3.0$ \\
\hline
\end{tabular}

Fig.1 Different types of cow urine

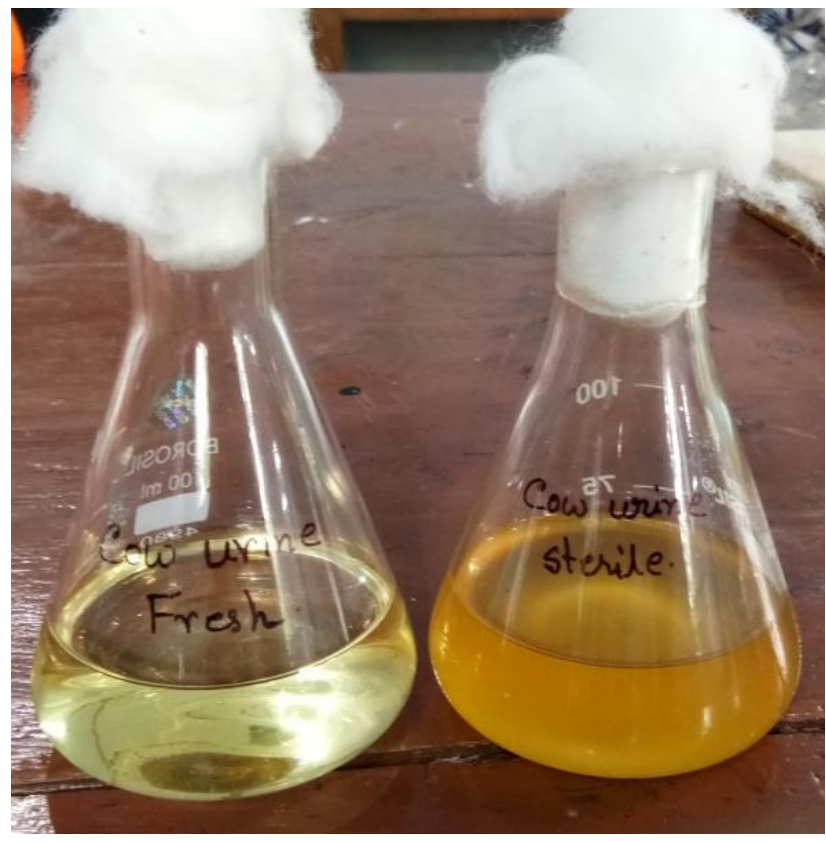



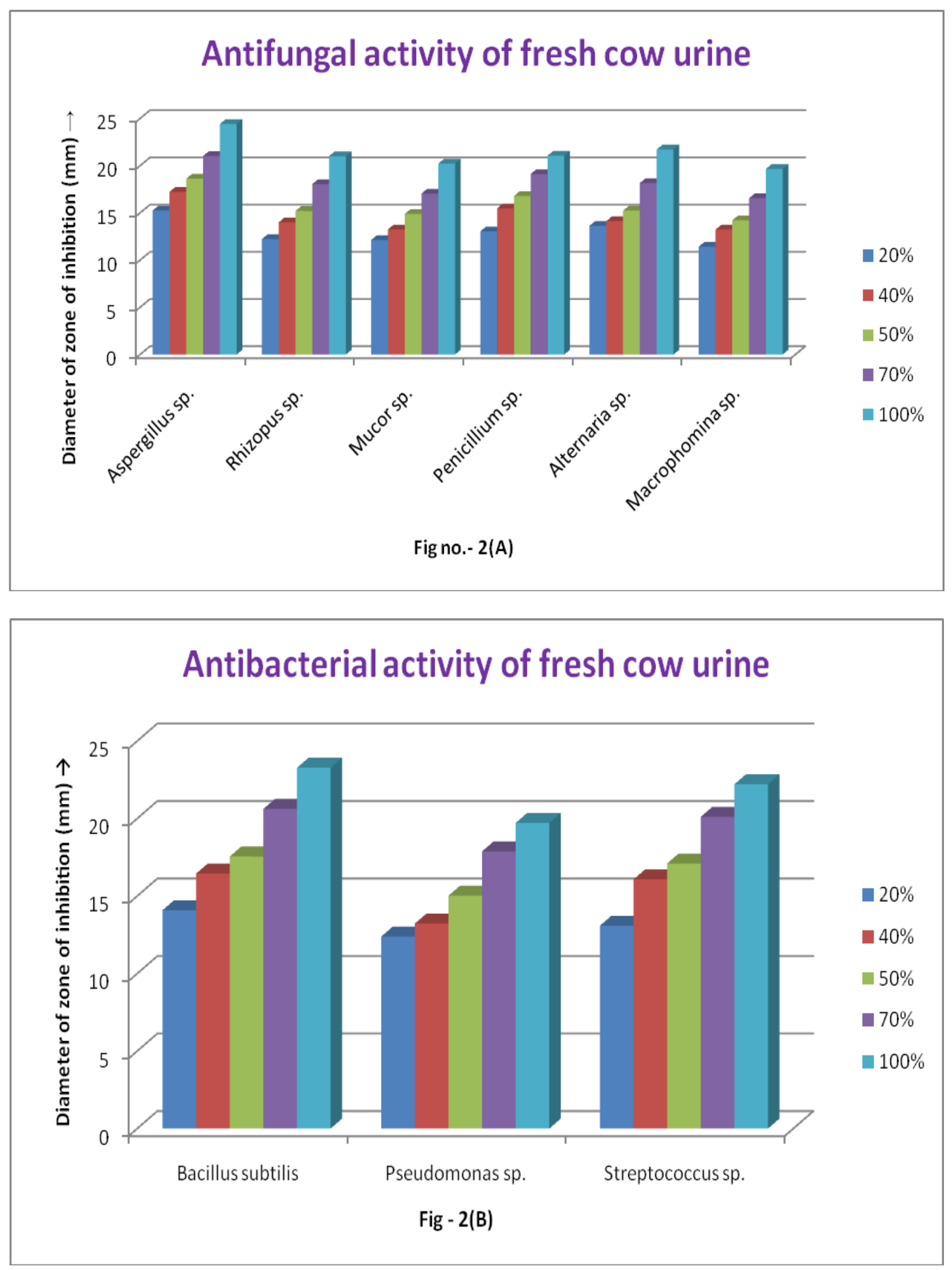

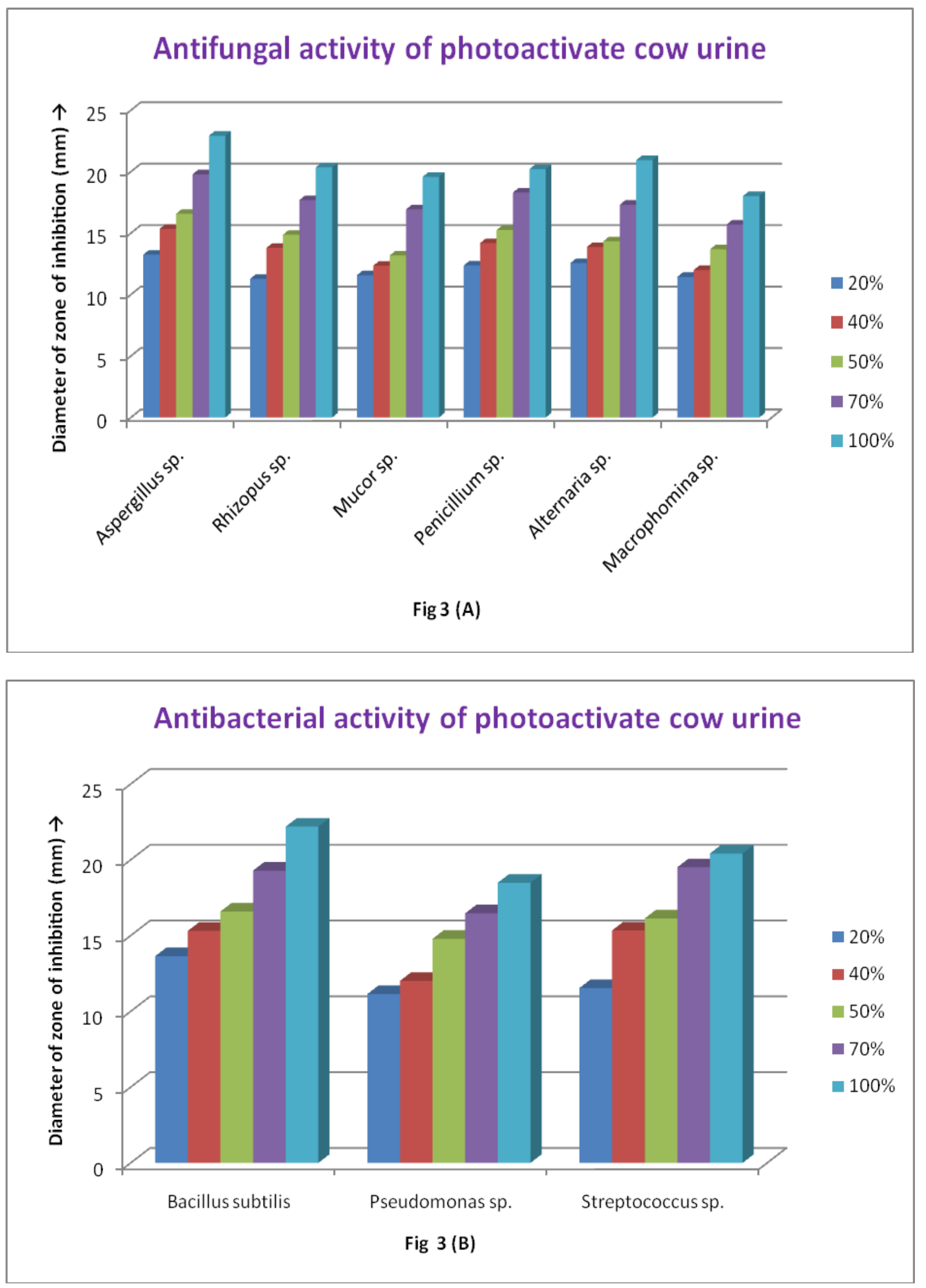


\section{Antifungal activity of sterile cow urine}

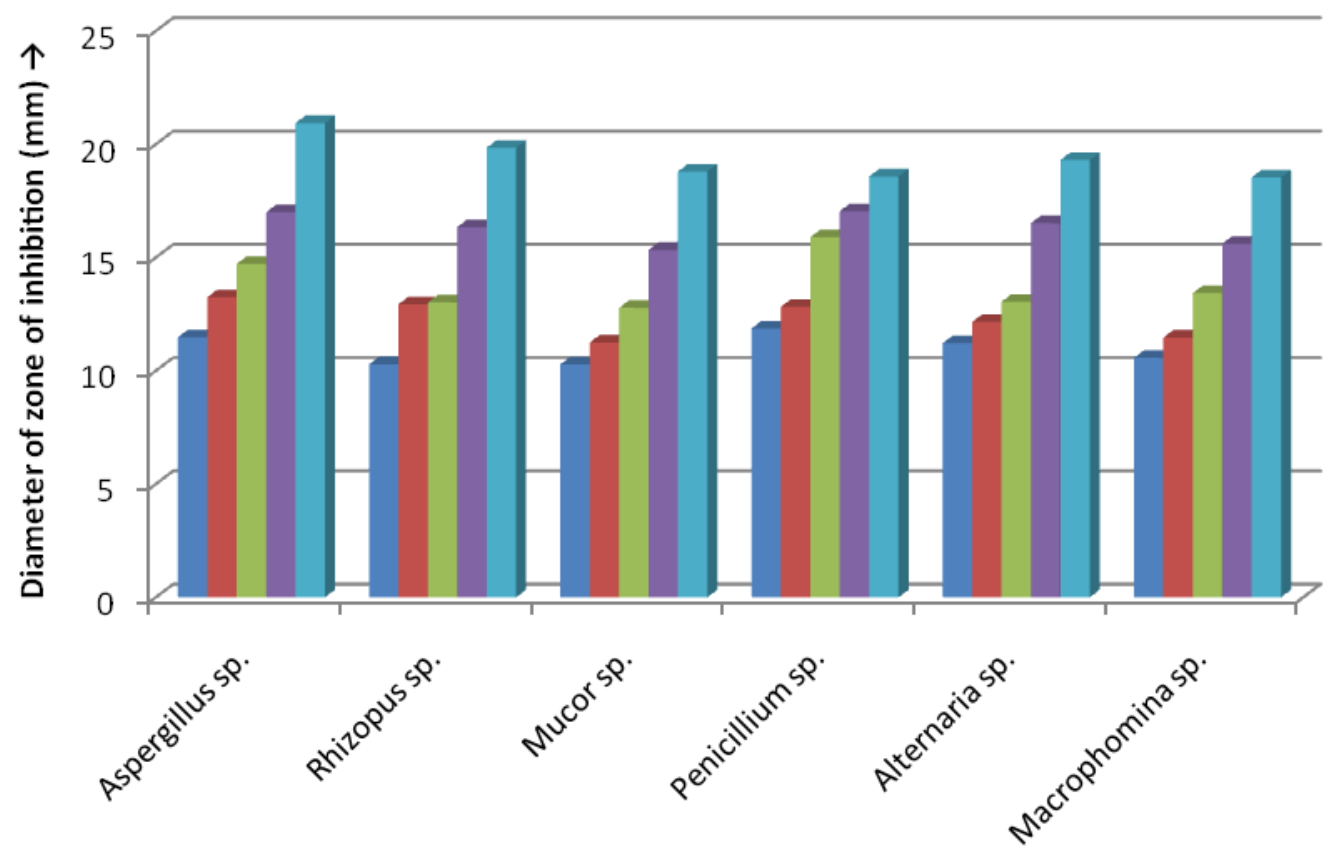

- $20 \%$

- $40 \%$

- $50 \%$

- $70 \%$

- $100 \%$

Fig 4 (A)

Antibacterial activity of sterile cow urine

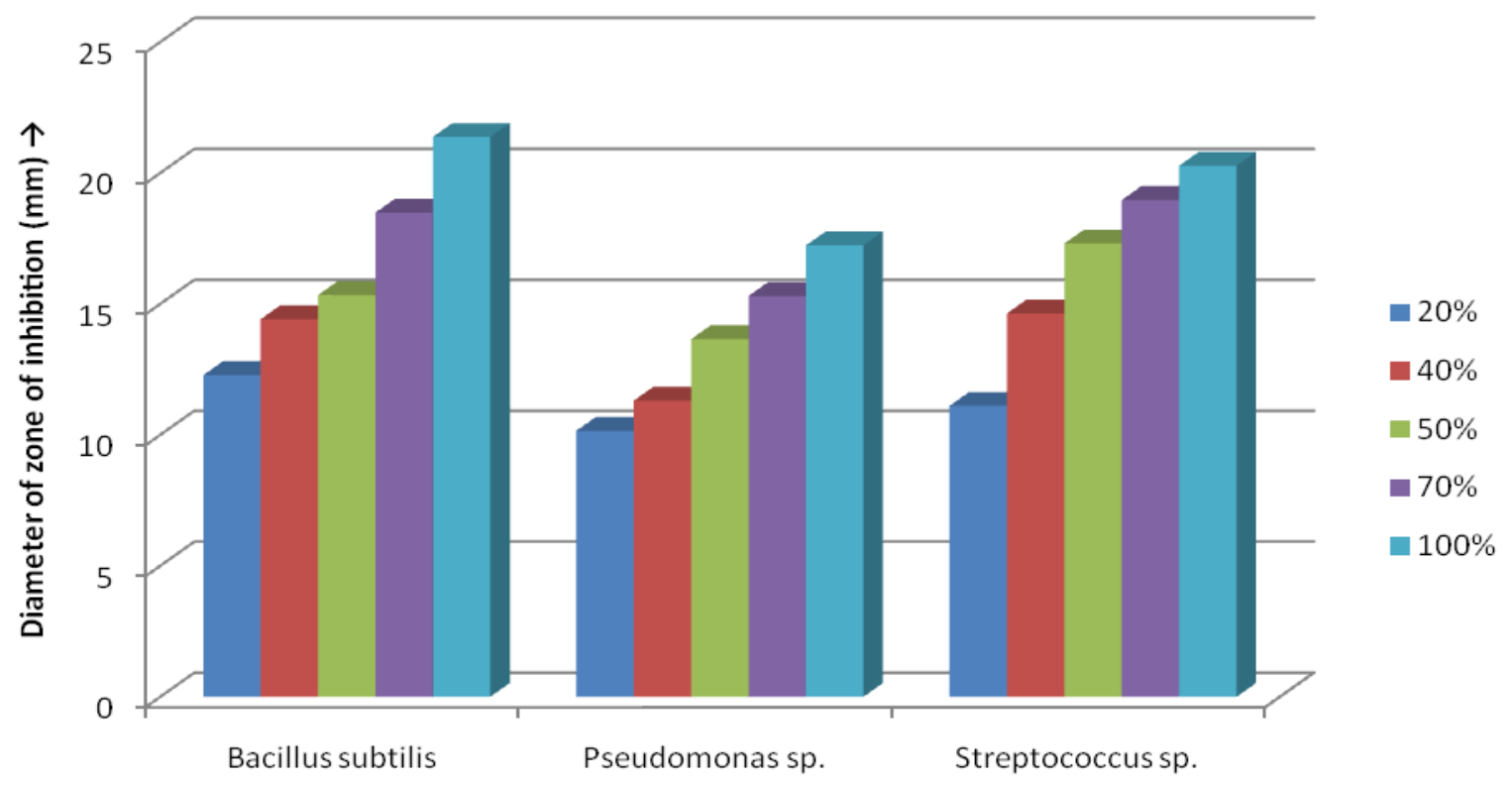

Fig 4 (B) 
Fig.5 Efficacy of cow urine as antifungal agent

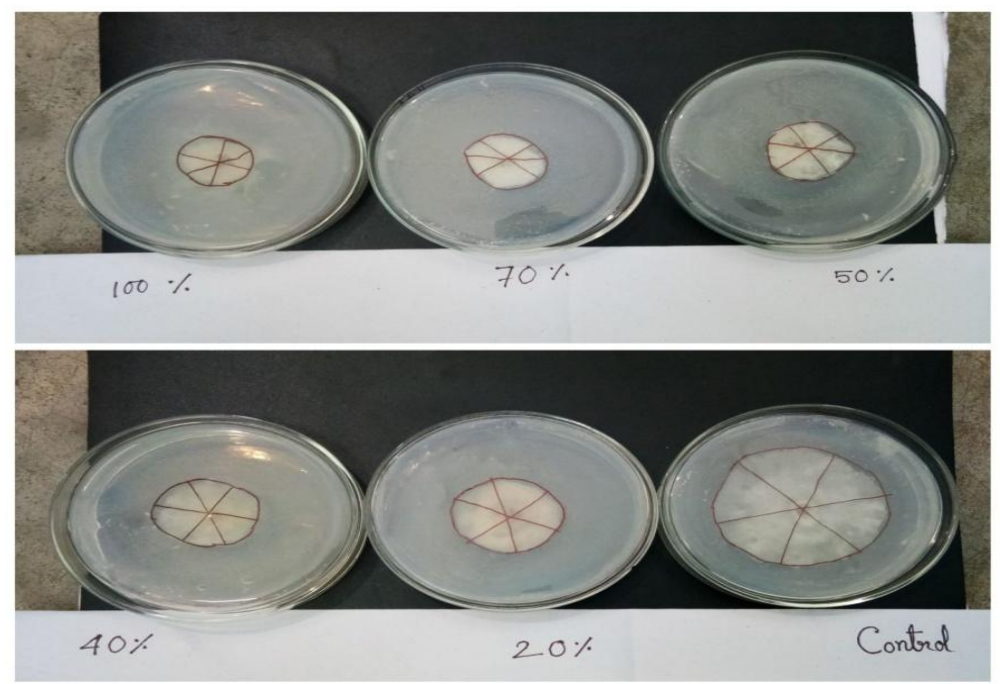

Fig.6 Efficacy of cow urine as antifungal agent

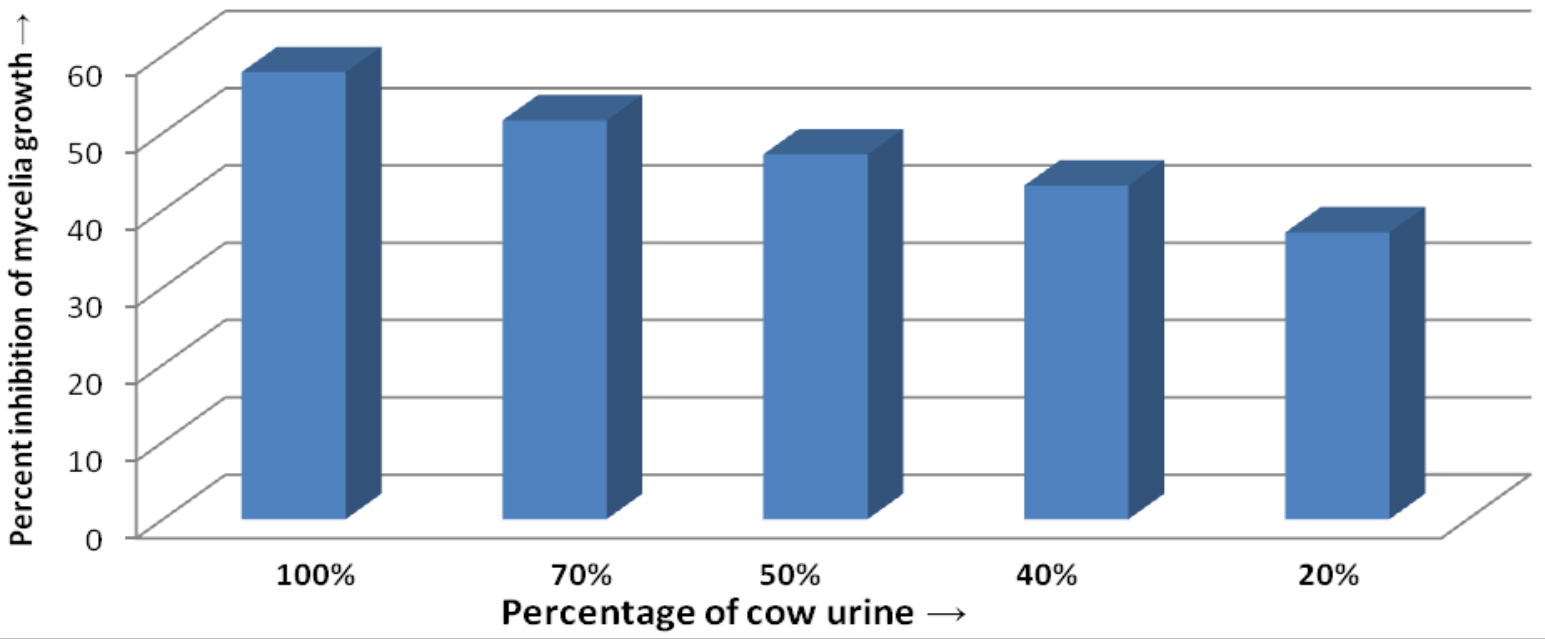

Result of determining the efficacy of cow urine as antifungal agent

\begin{tabular}{|c|c|c|c|}
\hline $\begin{array}{c}\text { SL } \\
\text { NO. }\end{array}$ & PERCENTAGE & $\begin{array}{c}\text { COLONY } \\
\text { OF COW URINE }\end{array}$ & $\begin{array}{c}\text { PERCENTAGE OF INHIBITIONOF } \\
\text { DIAMIETER }(\mathbf{m m})\end{array}$ \\
\hline $\mathbf{1}$ & $0 \%(\mathrm{control})$ & 59.30 & 0.0 \\
\hline 2 & $20 \%$ & 37.30 & 37.09 \\
\hline 3 & $40 \%$ & 33.70 & 43.17 \\
\hline 4 & $50 \%$ & 31.30 & 47.21 \\
\hline 5 & $70 \%$ & 28.70 & 51.60 \\
\hline 6 & $100 \%$ & 25.00 & 57.84 \\
\hline
\end{tabular}


The highest zone of inhibition was shown against Aspergillus sp while the smallest zone of inhibition was shown against Macrophomina sp in fresh cow urine. The highest zone of inhibition was shown against Aspergillus sp while the smallest zone of inhibition was shown against Pseudomonas sp in photoactivated cow urine. The highest zone of inhibition was shown against Bacillus subtilis while the smallest zone of inhibition was shown against Pseudomonas sp in sterile cow urine.

In our study it was reconfirmed that the cow urine possesses antimicrobial properties. From our study we came to a conclusion that urine from different cows had different level of antimicrobial properties. The difference in level of antimicrobial properties of different cow urine may be because of difference in chemical composition of urine which may arise due to several reasons. We found out in our studies that fresh cow urine was more effective antimicrobial agent than photo activated urine this may be because fresh urine is more acidic in nature. The microbial zones of inhibition values are given in the Table 1.

\section{Result of determining the efficacy of cow urine as antifungal agent}

In the present studies Aspergillus sp fungal pathogens was isolated from the oil and cereal crop seed. Data presented in Table 2 that all percentages $(20 \%, 40 \%, 50 \%, 70 \%$ and $100 \%$ $\mathrm{v} / \mathrm{v})$ of cow urine were effective against the growth of the fungus which exhibited the significant inhibition in the growth of fungal plant pathogens. With increase in concentration of cow urine there was corresponding increase in the inhibition of vegetative growth of the fungal pathogens. The diameter of the fungal colonies in poisoned plates was lesser when compared to control plates and it indicates the antifungal effect of cow urine. Maximum inhibition was shown in $100 \%$ pure cow urine and minimum inhibition was shown in $20 \%$ cow urine plate.

\section{Possible uses of cow urine and future aspect}

Medical uses of cow urine has been reported in a lot of literature and indicated to be beneficial even for dreaded diseases like cancer, AIDS and diabetes. Practitioners of Ayurvedic medicine from India routinely use cow urine as a remedy and the medicines made from it are used to cure several diseases. Improvements have been shown or reported with those suffering from flu allergies, colds, rheumatoid arthritis, bacterial/viral infections, tuberculosis, chicken pox, hepatitis, leucorrhoea, leprosy, ulcer, heart disease, asthma, skin infections, aging, chemical intoxication etc. Cow urine can kill the number of drug resistant bacteria and viruses. Recently the cow urine has been granted U.S. Patents (No, 6,896,907) for its medicinal properties, particularly as a bioenhancer and as an antibiotic, antifungal and anticancer agent as an anti-cancer agent it increases the potency of 'Taxol'(Paclitaxel) against MCF7, a human breast cancer cell line, in in-vitro assays (US Patent No. 6,410,059).

Through extensive research studies a cow urine distillate fraction, popularly known as 'ark', has been identified as a bioenhancer of the activities of commonly used antibiotics, anti-fungal and anti-cancer drugs. Thus it can promote and augment the bioactivity or bioavailability or the uptake of drags in combination therapy and reduce the dose and duration of treatment. These milestone achievements highlight the beneficial role of cow urine in treating bacterial infections and cancers and that cow urine enhances the efficacy and potency of therapeutic drugs. During the past few years cow urine therapy has provided promising and authentic results 
for the treatment of cancer, a deadly malady which is being faced by the mankind and the incidences of which are ever increasing in the current scenario of changed life style and food habits along with exposure to predisposing factors of carcinogens such as tobacco chewing, smoking, alcohol intake., environmental pollutants, occupational health hazards etc. Anticancer potential of cow urine therapy has been reflected by several case reports success stories and practical feedback of patients for the treatment of cancer. Cow urine enhances the immunocompetence and improves general health of an individual: prevent the free radicals formation and act as anti-aging factor; reduces apoptosis in lymphocytes and helps them to survive; and efficiently repairs the damaged DNA, thus is effective for the cancer therapy.

As cow urine showed remarkable antibacterial activity against the pathogenic bacteria, for which it can be selected for further studies to isolate bioactive natural constituents that may address to unmet therapeutic needs. Such screening of various natural compounds and identifying active agents is the needful, because successful prediction of lead molecule and drug like properties at the onset of drug discovery will pay off later in drug development. But in vivo studies on these cow urine preparations are necessary and should seek to justify its potential as antimicrobial agent. The use of cow urine is a cost effective and ecofriendly approach to control phytopathogenic fungi. The present study has shown a concentrations dependent inhibition of fungi isolated from ginger various oil and cereal crop seed. It can be concluded that cow urine can be used to control various fungal and bacterial disease. It is also observed in the study that storage of cow urine would result in enhancement of the inhibitory efficacy. Further, field studies are to be carried out to justify the possible utilization of cow urine against fungal infection.

\section{References}

"World Intellectual Property Organization" http://www.wipo.int/pctdb/en/wo.jsp?WO $=2003 / 020038$. 1185p. (cited on 2013, Oct. 10)

Achliya GS, Meghre VS, Wadodkar SG, Dorle AK. Antimicrobial activity of different fractions of cow urine. Indian $\mathrm{J}$ Nat Prod 2004; 20: 14-6.

Akhter N, Begum F, Alam S, Alam MS; Inhibitory effect of different plant extracts, cow dung and cow urine on conidial germination of Bipolaris sorokiniana. J. bio-sci., 2006; 14: 87-92.

Aruna R, and Spadmapriya S., Evaluation of antimicrobial activity of indigenous cow urine against bacterial fish pathogens. International Journal of Zoology Studies, 2016; 1(4): 29-31.

Ashlesha, and Paul YS; Antifungal bioefficacy of organic inputs against fungal pathogens of bell pepper. Paripex- Indian Journal of Research, 2014; 3(6): 4-9.

Ashlesha, Thakur S, Paul YS, Rameshwar, Payal; Antifungal activity of cow urine distillates of local botanicals against major pathogens of bell pepper. African Journal of Agricultural Research, 2013; 8(48): 6171-6177.

Badadani M, SureshBabu SV, Shetty KT. Optimum conditions of autoclaving for hydrolysis of proteins and urinary peptides of prolyl and hydroxyprolyl residues and HPLC analysis. $\mathbf{J}$ Chromatogr B Analyt Technol Biomed Life Sci 2007; 847: 267-74.

Chauhan RS, and Singhal L. Harmful effects of Pesticides and their control through cowpathy. Int J Cow Sci 2006; 2: 61-70.

Chauhan RS, Singh BP, Singhal LK. Immunomodulation with kamdhenu Ark in mice. J Immunol Immunolpathol 2001; 71: 89- 92.

Chauhan RS. Panchagavya therapy (cow pathy) - Current status and future directions. Indian Cow 2004; 1: 3-7. 
Deshmukh SS, Rajgure SS, Ingole SP; Antifungal activity of cow urine. IOSR Journal of Pharmacy, 2012; 2(5): 27-30.

Edwin J, Sheej E, Vaibhav T, Rajesh G, Emmanuel T. Antioxidant and antimicrobial activities of cow urine. Global journal of pharmacology 2008; 2(2): 20- 22.

Gotora T, Masaka L, Sungirai M; Effect of cow urine on the growth characteristics of Fusarium lateritium, an important coffee fungus in Zimbabwe. International Journal of Agronomy, 2014; Volume 2014, Article ID 986068, 4 pages, dx.doi.org/10.1155/2014/986068.

Hu W, Murphy MR, Constable PD, Block E. Dietary cation-anion difference effects on performance and acid-base status of dairy cows postpartum. J Dairy Sci 2007; 90: 3367-75.

Jain NK, Gupta VB, Garg R, Silawat N. Efficacy of cow urine therapy on various cancer patients in Mandsaur District, India - A survey. Int J Green Pharm 2010; 4: 29-35.

Jain NK, Gupta VB, Garg R, Silawat N. Efficacy of cow urine therapy on various cancer patients in Mandsaur District, India -A survey. Int J Green Pharm 2010; 4: 29-35.

Jarald E, Edwin S, Tiwari V, Garg R, Toppo E. Antioxidant and antimicrobial activities of cow urine. Glob J Pharmacol 2008; 2: 20-2.

Kambar Y, Vivek MN, Manasa M, Kekuda PTR, Nawaz NAS; Inhibitory effect of cow urine against Colletotrichum capsici isolated from anthracnose of Chilli (Capsicum annuum L.). Science Technology and Arts Research Journal, 2013; 2(4): 91-93.

Kekuda PTR, Akarsh S, Nawaz NAS, Ranjitha $\mathrm{MC}$, Darshini SM, Vidya $\mathrm{P}$; In vitro antifungal activity of some plants against Bipolaris sorokiniana (Sacc.) Shoem. International Journal of Current Microbiology and Applied Sciences, 2016; 5(6): 331-337.
Kekuda PTR, Vivek MN, Manasa M, Kambar Y, Nawaz NAS, Raghavendra HL; Antifungal effect of cow urine extracts of selected plants against Colletotrichum capsici isolated from anthracnose of chilli. International Journal of Agriculture and Crop Sciences, 2014; 7(3): 142-146.

Kirtikar KR, and Basu BD. Indian Medicinal Plants, 2nd edition. Dehra Dun, Bishen Singh, Mahendra Pal Singh, 2003; 3: 1646.

Krishnamurthi K, Dutta D, Devi SS, Chakrabarti T. Protective effect of distillate and redistillate of cow's urine in human polymorphonuclear leucocytes challenged with established genotoxic chemicals. Biomed Environ Sci 2004; 17: 57- 66.

Kumar AA. Study on Various Biochemical Constituents in the Urine of Cow, Buffalo and Goat. Thesis Submitted to the C.S.A. Univ Agr Techn, Kanpur (U.P.); 2001. p. 13.

Kumar S. Analysis of cow's urine for detection of lipase activity and anti-microbial properties. J Pharm Biol Sci 2013; 7: 1-8.

Mehta R, and Khan NS; Medicinal plants \& cow's excrement: An estimable wealth of nature. Journal of Pharmaceutical and Biological Research, 2014; 2(2): 156-159.

Mohanty I, Senapati MR, Jena D, Pallai S. Diversified uses of cow urine. Int J Pharm Pharm Sci 2014; 6: 20-2.

Naotoshi K, Osamu Y, Yoshihiko S, Fuminobu M, Masahiro Y, Yoshimitsu M. Clinicopathological findings in peripartum dairy cows fed anion salts lowering the dietary cation-anion difference: Involvement of serum inorganic phosphorus, chloride and plasma estrogen concentrations in milk fever. Jpn J Vet Res 2007; 55: 3-12.

Pathak ML, and Kumar A. Cow praising and importance of Panchyagavya as medicine. Sachitra Ayurveda 2003; 5: 56-59.

Pathak ML, and Kumar A. Gomutra descriptive study. Sachitra Ayurveda 2003; 7: 81-84.

Pescheck-Böhmer F, and Schreiber G. Healing yourself using urine. Urine Therapy: 
Nature's Elixir for Good Health. Rochester: Inner Traditions, Bear \& Company; 1999. p. 152.

Rakesh KN, Dileep N, Junaid S, Kekuda PTR, Vinayaka KS, Nawaz NAS; Inhibitory effect of cow urine extracts of selected plants against pathogens causing rhizome rot of ginger. Science Technology and Arts Research Journal, 2013; 2(2): 92-96.

Randhawa GK, and Sharma R; Chemotherapeutic potential of cow urine: A review. Journal of Intercultural Ethnopharmacology, 2015; 4(2): 180186.

Ruchira T, Tewari AK, Brijesh B, Puspendra S, Megha P; Role of cow urine in beekeeping and crop protection in Uttarakhand, India. Research Journal of Recent Sciences, 2016; 5(ISC-2015): 100-107.

Shah E. Herbal composition in cow urine distillate. US5693327. 1997.

Shanthi S, Elamathy S, Panneerselvam A, Radha N; Antixanthomonas activity of Pongamia pinnata linn leaves - cow urine extract- a natural cost effective ecofriendly remedy to bacterial leaf blight of paddy (BLB). Journal of Pharmacy Research, 2011; 4(3): 650-652.

Shaw SL, Mitloehner FM, Jackson W, Depeters EJ, Fadel JG, Robinson $\mathrm{PH}$, et al., Volatile organic compound emissions from dairy cows and their waste as measured by proton transfer-reaction mass spectrometry. Environ Sci Technol 2007; 41: 1310-6.

Singh UP, Maurya S, Singh A, Nath G, Singh M. Antimicrobial efficacy, disease inhibition and phenolic acid-inducing potential of chloroform fraction of cow urine. Arch Phytopathol Plant Protect 2012; 45: 1546-57.

Singla S, and Garg R. Cow urine: An elixir. Innov J Ayur Sci 2013; 1: 31-5.

Swami CS, and Alane SK; Efficacy of some botanicals against seed - borne fungi of green gram (Phaseolus aureus Roxb.). Bioscience Discovery, 2013; 4(1):107110.

Tiwari RKS, and Das K; Inhibitory effect of cow urine based plant extracts against Rhizoctonia solani causing sheath blight of rice. Indian Phytopathology, 2011; 64(3): 265-268.

Türi M, Türi E, Kõljalg S, Mikelsaar M. Influence of aqueous extracts of medicinal plants on surface hydrophobicity of Escherichia coli strains of different origin. APMIS 1997; 105: 956-62.

Upadhyay RK, Dwivedi P, Ahmad S. Antimicrobial activity of photoactivated cow urine against certain pathogenic bacterial strains. Afr J Biotechnol 2010; 9: 518-22.

Yadav H, Yadav M, Jain S, Bhardwaj A, Singh V, Prakash O, Marotta F; Antimicrobial property of herbal preparation containing Dalbergia sissoo and Datura tramonium with cow urine against pathogenic bacteria. International Journal of Immunopathology and Pharmacology, 2008; 21(4): 1013-1020.

\section{How to cite this article:}

Tanmay Ghosh and Biswas, M.K. 2018. Evaluation of Antibacterial and Antifungal Activity of Cow Urine against Some Seed Borne Microflora. Int.J.Curr.Microbiol.App.Sci. 7(05): 1714-1727. doi: https://doi.org/10.20546/ijcmas.2018.705.201 